\title{
パルプ蒸解工程排水を対象とした嫌気性処理シ ステムの長期運転実績
}

\section{The Long Experience of Anaerobic Wastewater Treatment System for Pulp Mill Wastewater}

\author{
住友重機械エンバイロメント株式会社 環境技術センター*2 \\ ○知久治之*3, 竹繁隆徳，島本敦史，渡邊永子 \\ 同 環境システム統括部 事業企画部 \\ 中野 淳
}

Haruyuki Chiku*3, Takanori Takeshige, Atsushi Shimamoto, Nagako Watanabe and Atsushi Nakano Development and Analysis Center, Sumitomo Heavy Industries Environment Co., Ltd. ${ }^{* 2}$

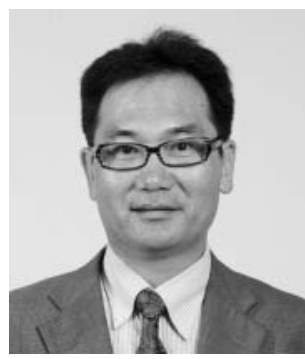

知久治之

\begin{abstract}
The EGSB anaerobic wastewater treatment system is a very competitive method compared with aerobic treatment system because of space and energy saving system. We constructed the Biobed EGSB system in Pulp Mill for the treatment of drain wastewater from KP evaporator and operated over five years.

The performance of EGSB system is good as for the removal rate of $\mathrm{COD}_{\mathrm{Cr}}$ is about $80 \%$, then we achieved the aimed energy-saving effect.
\end{abstract}

分類 : $\mathrm{F}_{0}$ その他, $\mathrm{X}_{4}$ 排水

\section{1.はじめに}

$\mathrm{UASB} / \mathrm{EGSB}$ 嫌気性処理システムは好気性処理システ ムに比べ，超高負荷運転が可能なため著しく省スペースな 装置となること, また必要動力が少なく, かつ発生するバ イオガスからエネルギー回収が可能であるため, 著しくエ ネルギー効率が良いこと, 更には余剩污泥発生量が極めて 少ないという有利な特徵を持つため, 1980 年代後半から 全世界で適用拡大されてきている。このシステムは 2000 年には国内でも 180 基以上が稼動していると言われてい る ${ }^{1)}$ 。当社はUASB/EGSB 嫌気性処理システムにおいて

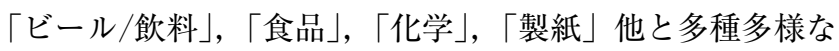
経験と計 80 基以上の納入実績を持ち, UASB/EGSB にお

\footnotetext{
${ }^{* 1}$ 平成 24 年度年次大会講演（講演 No. C 02）

*2 \%237-8555 神奈川県横須賀市夏島町 19 番地/

19 Natsushima-cho, Yokosuka-shi, Kanagawa 237-8555, Japan

${ }^{* 3}$ E-mail : hry_chiku@shi.co.jp
}

いての国内主カメーカーとして位置づけている。

前回 ${ }^{2}$, 王子製紙株式会社富岡工場納入実設備の試運転 から 1 年間の運転実績の報告を行ったが, 今回はその運転 開始から 5 年以上に渡る長期実設備運転状況をグラニュー ル污泥の群集解析結果を交えて報告する。

\section{2. 対象排水について}

処理対象排水は紙パルプ工場排水の中でも高濃度排水と してクラフトパルプ製造過程で発生する臭気排水とした。 富岡工場では, 従来臭気排水をスチームストリッピング後, 活性污泥法にて処理していた。この臭気排水を直接嫌気性 処理することで, 先に示した嫌気処理自体のメリットに加 え，ストリッピングに要していた蒸気使用量が削減できる という大きなメリットが生じる2)。

この臭気排水の分析結果を表 1 に示す。 $\mathrm{COD}_{\mathrm{Cr}}$, メ夕ノー ル濃度が高く, 有機物の主体はメタノールであった。臭気 源である全還元性イオウ（TRS）や，樹脂酸やテルペンに 起因する $\mathrm{n}$-ヘキサン抽出物質（油分）を含む排水である。 また，濃度変動の大きい排水である。EGSB 嫌気性処理シ 
表 1 臭気排水分析結果

\begin{tabular}{|c|c|c|}
\hline 項目 & 単位 & 分析值 \\
\hline $\mathrm{pH}$ & - & $6 \sim 10$ \\
\hline SS & $\mathrm{mg} / \mathrm{l}$ & $2 \sim 15$ \\
\hline $\mathrm{COD}_{\text {cr }}$ & $\mathrm{mg} / \mathrm{l}$ & $11,000 \sim 16,000$ \\
\hline CODMn & $\mathrm{mg} / 1$ & $3,600 \sim 5,700$ \\
\hline $\mathrm{BOD}$ & $\mathrm{mg} / \mathrm{l}$ & $2,600 \sim 6,000$ \\
\hline メタノール & $\mathrm{mg} / \mathrm{l}$ & $5,700 \sim 7,000$ \\
\hline $\mathrm{n}$-ヘキサン抽出物 & $\mathrm{mg} / \mathrm{l}$ & $170 \sim 540$ \\
\hline $\mathrm{T}-\mathrm{N}$ & $\mathrm{mg} / \mathrm{l}$ & $190 \sim 260$ \\
\hline $\mathrm{T}-\mathrm{P}$ & $\mathrm{mg} / \mathrm{l}$ & $<1$ \\
\hline TRS*) & $\mathrm{mg} / \mathrm{l}$ & $200 \sim 470$ \\
\hline
\end{tabular}

*)TRS：全還元性イオウ Total Reduced Sulfur

ステムにはこの臭気排水の油分を粗取り後， 2 倍以上希釈 して投入している。また，この排水は発酵学的に栄養がそ しいため, 当社オリジナルの添加剤である MFーサプリ（有 機栄養源）と $\mathrm{MF}-8+1$ (無機栄養源) および鉄と燐酸を 添加している。

\section{3. 実設備ついて}

実設備納入前のラボテスト結果と設備計画の条件を表 2 に示す。テスト結果を基に, 設備化検討を行った。ラボテ ストは，均一な原水を管理された状態で処理するのに対し， 実設備では原水流量や濃度, 組成が製造工程の状況に応じ て常に変動する。従って, ラボテスト結果と比べて, 若干 余裕のある計画条件とした。

設備概要を表 3 に，概略フローを図 1 に，実設備写真を 写真 1 に示す。

臭気排水の温度は高いため, $38^{\circ} \mathrm{C}$ 以下に温度調節後, 設 備に受け入れることとした。また，排水は油分を含むため， 油分分離槽を設けて油分濃度の低減を図った。嫌気性処理 システムとして, Bioimpact ${ }^{\circledR}$ EGSB システムを採用した。

表 2 ラボテスト結果および設備計画条件

\begin{tabular}{c|c|c|c}
\hline 項目 & 単位 & テスト結果 & 計画条件 \\
\hline $\mathrm{COD}_{\mathrm{Cr}}$ 容積負荷 & $\mathrm{kg} / \mathrm{m}^{3} \mathrm{~d}$ & 18 & 15 \\
メタノール容積負荷 & $\mathrm{kg} / \mathrm{m}^{3} \mathrm{~d}$ & 9 & 7.5 \\
希釈率 & - & 2 & 2 \\
$\mathrm{COD}_{\mathrm{Cr}}$ 除去率 & $\%$ & 90 & 80 \\
メタノール除去率 & $\%$ & 95 & 95 \\
ガス化率 & $\mathrm{Nm}^{3} / \mathrm{COD} \mathrm{Cr}$ & 0.2 & 0.2 \\
メタン濃度 & $\%$ & 90 & 80 \\
\hline
\end{tabular}

表 3 設備の概要

\begin{tabular}{c|c}
\hline 臭気排水処理能力 & $1,600 \mathrm{~m}^{3} / \mathrm{d}$ \\
\hline バイオガス発生量 & $200 \mathrm{Nm}^{3} / \mathrm{h}\left(80 \% \mathrm{CH}_{4}\right)$ \\
\hline エネルギー回収量 & $137,000 \mathrm{MJ} / \mathrm{d}$ \\
\hline 主要機器概要 & \\
油分分離槽 & $75 \mathrm{~m}^{3}$ \\
酸生成槽 & $160 \mathrm{~m}^{3}$ \\
EGSB 反応槽 & $1,300 \mathrm{~m}^{3}$ (有効) \\
ガスホルダー & $100 \mathrm{~m}^{3}$ \\
\hline
\end{tabular}

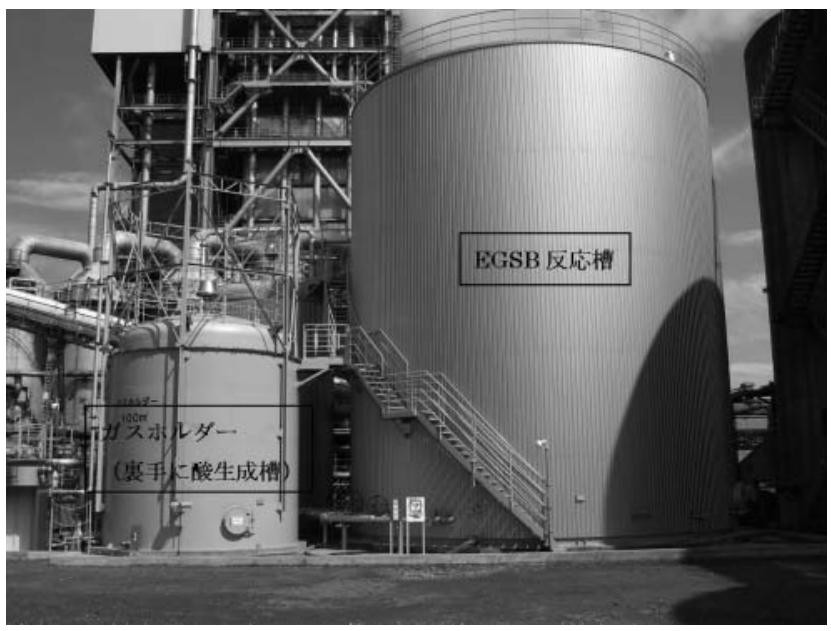

写真 1 実設備写真

システムは，図 1 ，写真 1 に示すように酸生成槽と EGSB 反応槽とシンプルに構成される。反応槽には，グラニュー ル污泥が充填されており，排水中に含まれる有機物をメ夕

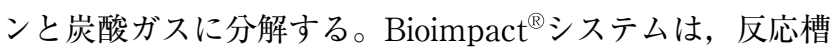
内でグラニュール污泥の均一な流動状態を形成し, 流入水 と污泥が良好に接触して嫌気性反応を進行できるように設 計している。反応槽上部には高性能セトラーが設置され, 処理水とバイオガス, グラニュール污泥を効果的に分離す る。セトラーの分離効率が高いため，グラニュール形成途 上の小粒径の污泥も反応槽内に保持することができ，セ卜 ラー下部に形成されるローリング流の効果で，グラニュー ルの成長を促進させている。

\section{4. 運転状況と群集解析の結果}

本設備は 2007 年に試運転 (実負荷運転)を開始した。こ の試運転期間後の運転データを以下にまとめる。

定常時の $\mathrm{COD}_{\mathrm{Cr}}$ 容積負荷とメタノール容積負荷並びに データを図 2 に示す。図内の「SD+連番」の表記は定修 等による嫌気性処理設備のシャットダウン期間を示してお り，このシャットダウンおよびシャットダウンからの定常 負荷までの立ち上げ期間のデータは省略している。定常時 の $\mathrm{COD}_{\mathrm{Cr}}$ 容積負荷は 7 $17 \mathrm{~kg} / \mathrm{m}^{3} \cdot \mathrm{d}$ (メ夕ノール容積負 


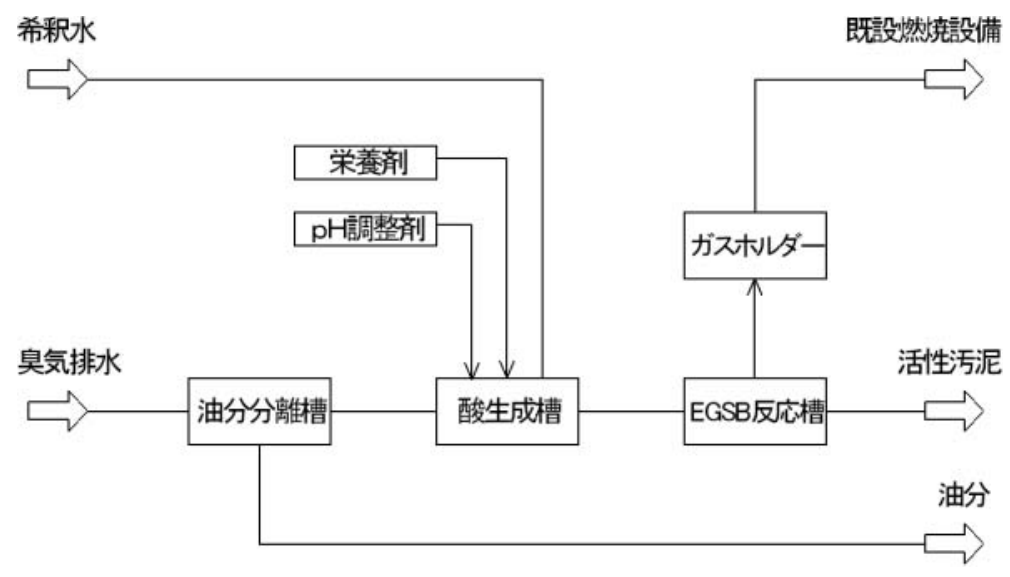

図 1 設備概略フロー

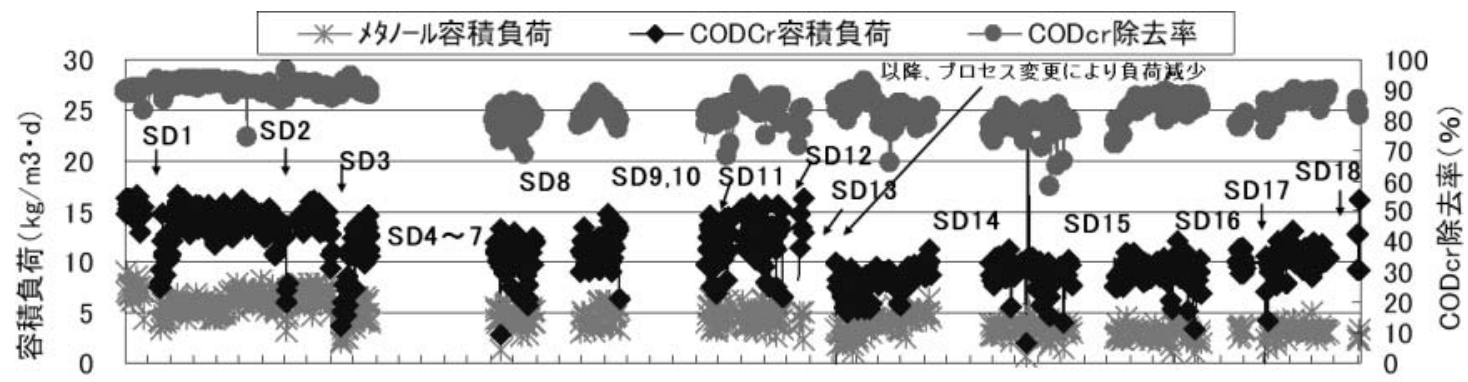

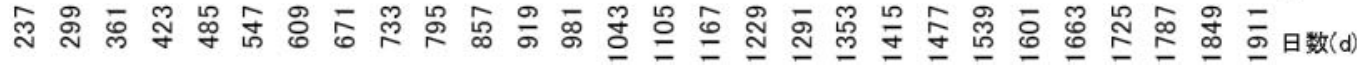
図 $2 \mathrm{COD}_{\mathrm{cr}}$ 容積負荷とメタノール負荷と $\mathrm{COD}_{\mathrm{cr}}$ 除去率

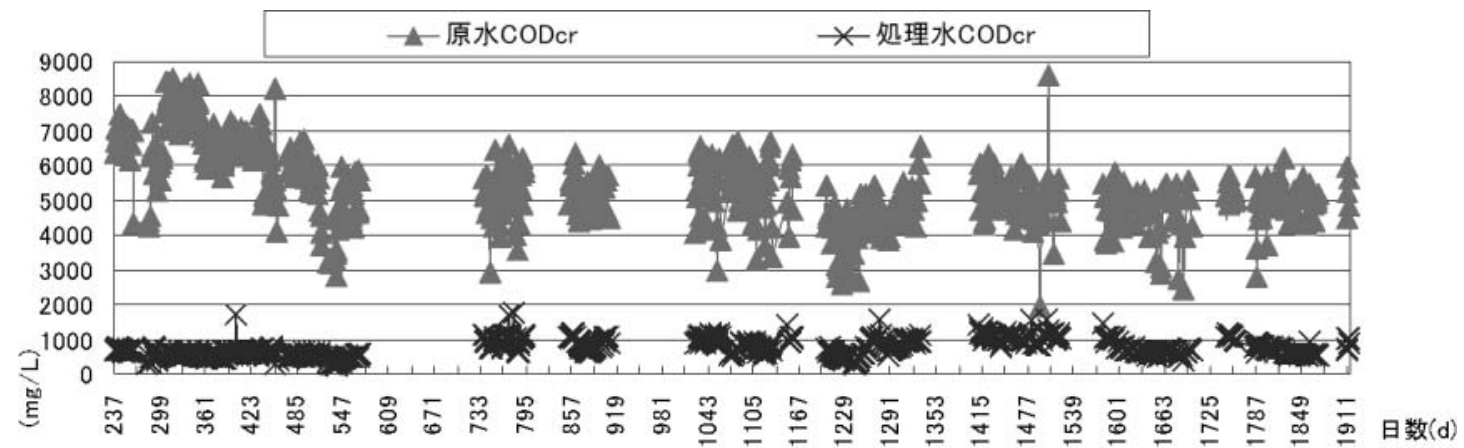

図 3 原水と処理水の $\mathrm{COD}_{\mathrm{cr}}$

荷は2 9 $\left.\mathrm{kg} / \mathrm{m}^{3} \cdot \mathrm{d}\right)$ であった。なお， 1,200 日目以降は 工場のプロセス変更等により, 臭気排水の負荷自体が減少 した。運転開始から 5 年間, 定常時の $\mathrm{COD}_{\mathrm{Cr}}$ 処理は原水 平均約 $5,000 \mathrm{mg} / \mathrm{L}$ が処理水平均で約 $1,000 \mathrm{mg} / \mathrm{L}$ と, 除 去率はほほ 80\%（期間によってはそれ以上）の処理性能 を示した（図 2, 図 3)。また定常時の処理水メタノールは $100 \mathrm{mg} / \mathrm{L}$ 以下を維持し，良好な処理を示した（図 4，図 5)。なお，試運転開始から全期間で EGSB 反応槽のグラ ニュールは維持されている（写真 2)。850日目から 1, 200 日目のほぼ 1 年の間に不特定の原因により一過性のグラ ニュールゾーン減少が確認され，1,245 日目に 1 度のみ試 運転開始時投入污泥量の $1 / 4$ 量と少量の種グラニュールを 追加投入しているが，それ以外は污泥の追加は行っていな

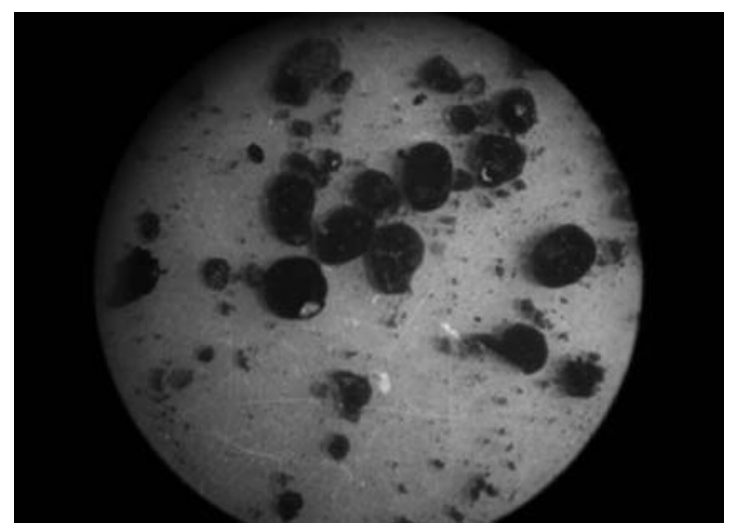

写真 2 EGSB 反応槽のグラニュール (1,146 日目) 


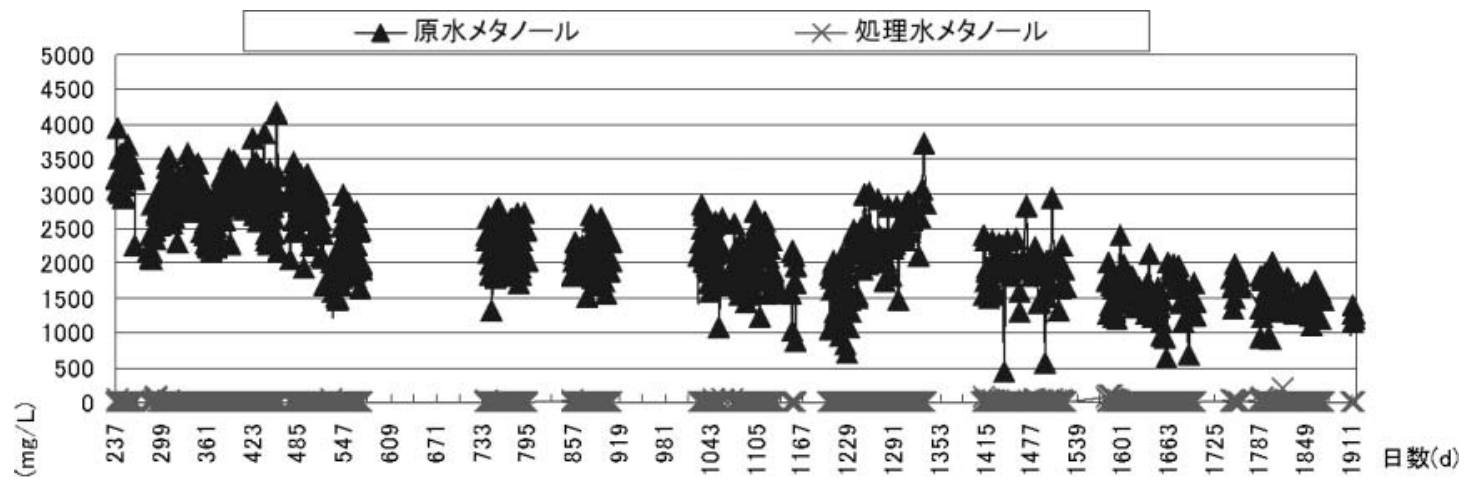

図 4 原水と処理水のメ夕ノール濃度

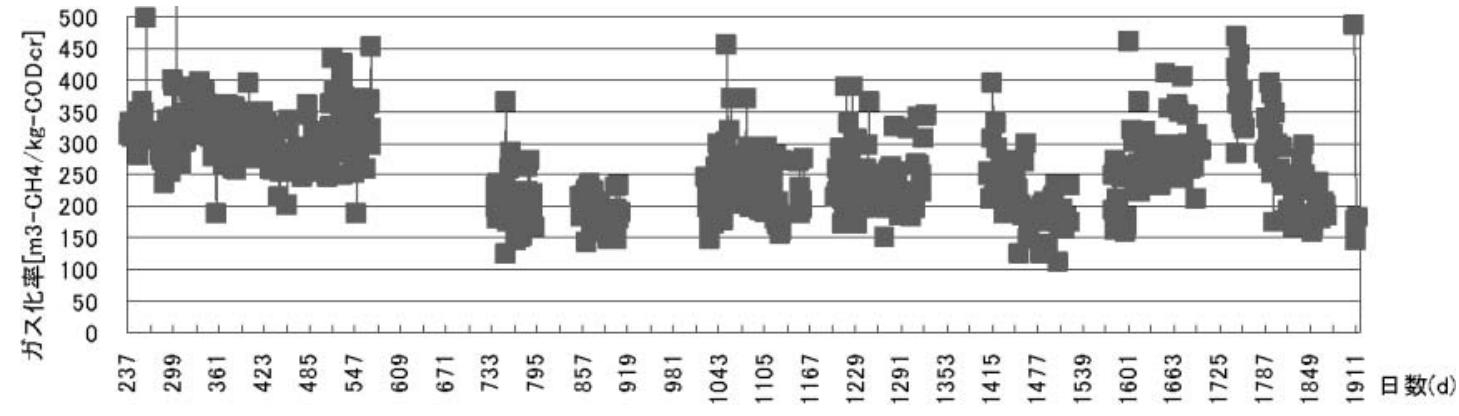

図 5 ガス化率

い。このグラニュールを構成する古細菌の菌叢を確認する ため, EGSB 反応槽のフロック污泥を除いたグラニュール のみを篩い分けし，16 SrDNA 法と T-RFLP 法により群 集解析を行った。このうち T-RFLP の結果を図 6 に示す。 嫌気性処理設備のシャットダウンが少なく，比較的高い除 去率で安定運転していた設備稼働当初は Methanomethylovorans spp. が増加する傾向であった。

その後，運転停止を繰り返す中で Methanomethylovorans spp. は減少し, Methanobacterium spp. が増加した。その後 もグラニュールを構成する古細菌の菌叢は大きく変化して いる。メタノールを直接資化できる Methanomethylovorans spp. はフロック性のためグラニュールとして維持しづら いと考えられているが，条件によってはグラニュールを構 成する主たる菌になり得るという結果が示された。
5. まと め

テスト/設備計画/実設備の性能の比較表を表 4 に示す。 5 年以上に渡る長期実設備運転を行っているが，定常時の 性能はラボテストで得られた性能とほぼ同等の性能を示し ていることが証明された。また，本設備では max. 133,000 $\mathrm{MJ} / \mathrm{d}$ ものメタンガス由来のエネルギーが回収されており, 単なる排水処理設備ではなく，エネルギー生産設備として も働いている。

なお，当初懸念されていた，污泥の維持や，シャットダ ウン明けの処理の悪化の問題も, MF-サプリ（有機栄養 源）と $\mathrm{MF}-8+1$ (無機栄養源) など有効な添加剂の適正 添加と $\mathrm{pH}$ および温度管理の徹底により, 安定運転が可能 であることが実証できた。

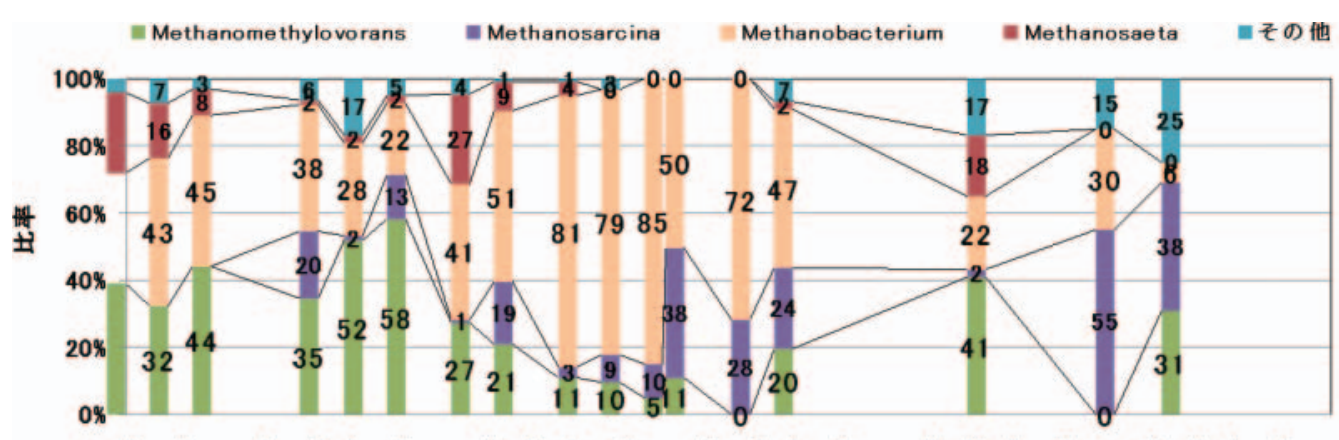

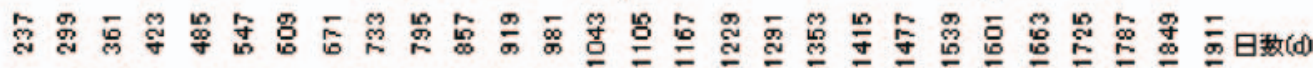

図 6 グラニュールを構成する古細菌比率 
表 4 テスト/設備計画/実設備の性能の比較表

\begin{tabular}{c|c|c|c|c}
\hline 項目 & 単位 & ラボテスト & 設備計画 & 実設備 \\
\hline $\mathrm{COD}_{\mathrm{Cr}}$ 容積負荷 & $\mathrm{kg} / \mathrm{m}^{3} \cdot \mathrm{d}$ & $\sim 18$ & $\sim 15$ & $\sim 17$ \\
メタノール容積負荷 & $\mathrm{kg} / \mathrm{m}^{3} \cdot \mathrm{d}$ & $\sim 9$ & $\sim 7.5$ & $\sim 9$ \\
希釈率 & - & 2 & 2 & 2 \\
$\mathrm{COD}_{\mathrm{Cr}}$ 除去率 & $\%$ & 90 & 80 & $80 \sim 93$ \\
メタノール除去率 & $\%$ & 95 & 95 & $80 \sim 100$ \\
ガス化率 & $\mathrm{Nm}^{3}-\mathrm{CH}_{4} / \mathrm{kg}-\mathrm{COD}_{\mathrm{Cr}}$ & 0.2 & 0.2 & $0.18 \sim 0.35$ \\
メタン濃度 & $\%$ & 90 & 80 & $89 \sim 99$ \\
エネルギー回収量 & $\mathrm{MJ} / \mathrm{d}$ & - & $\sim 137,000$ & $\sim 133,000$ \\
\hline
\end{tabular}

\section{6. おわりに}

当社はこの 5 年以上に渡る実設備運転経験と安定運転の 実績で, パルプ蒸解工程排水への嫌気性処理システムに関 して大きなアドバンテージが得られたものと考えている。

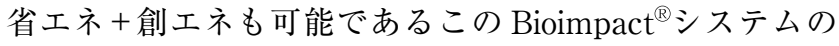
適用を広げ，当社が少しでも紙パルプ事業の効率化に役立 てることを希望する。

\section{Acknowledgement}

最後に，実設備の運転管理およびデー夕取得に惜しみな
いご協力をいただいた王子製紙株式会社/富岡工場様へ感 謝の意を表します。

\section{References}

1）原田秀樹ほか. 超高速メタン発酵バイオリアクターの 開発と污泥菌叢の分子微生物生態解析. 環境バイオテ クノロジー学会誌, Vol. 4, No. 1, p. 19-27, 2004.

2）中野淳ほか. パルプ蒸解工程排水への嫌気性処理シス テムの適用実績. 第 51 回 2008 年紙パルプ技術協会年 次大会要旨集 